\title{
Performance Measurement and Ranking Organization's Suppliers Based on Risk Factors Using a Hybrid Approach of FMEA and Multi- Criteria Decision Making Techniques: A Case Study
}

\author{
Davoud Jafari ${ }^{1}$ \& Mehrzad Lohrasbi ${ }^{1}$ \\ ${ }^{1}$ Department of Industrial Engineering, Parand Branch, Islamic Azad University, Tehran, Iran \\ Correspondence: Mehrzad Lohrasbi; Unit 5, No. 3, Tandis St., Nelson Mandela (Jordan) Blv., Tehran, Iran. Tel: \\ 98-9126-023-106. E-mail: mehrzad.lohrasbi92@yahoo.com
}

Received: May 19, 2018

Accepted: May 30, 2018

Online Published: September 29, 2018

doi:10.5539/mas.v12n10p149

URL: https://doi.org/10.5539/mas.v12n10p149

\begin{abstract}
Risk occurance in the supply chain is unavoidable. Basically, a great portion of these risks comes from suppliers. Timely identification of the risks and using appropriate preventive actions to reduce the probability and impact of their occurrence play a significant role in increasing organizational efficiency, improving product quality and satisfying customers. Developing a systematic and efficient mechanism is a prerequisite for properly identifying and assessing the supply chain risks and making correct decision. Failure Modes and Effects Analysis (FMEA) is a known engineering technique and risk assessment tool to define, identify, and eliminate potential failures and errors in the products, processes, projects, and services. In this paper, FMEA approach is combined with multicriteria decision-making techniques to make a systematic mechanism for assessing supply chain risks and prioritizing candidate flour suppliers in Sahar bread industrial group. In the proposed model, Analytic Hierarchy Process (AHP) is used to determine the risk's weights and VIKOR method is applied for assessing and ranking the suppliers. Results shew that among the identified risks, "cost risk group" with the weight "0.43" is the most important. Therefor the company officials have to adopt appropriate policies, carefully, to deal with this risk. Moreover, final evaluation of flour suppliers in the company indicates that according to all criteria, the fourth supplier achieves the highest priority and it is selected as the most qualified flour supplier for the company.
\end{abstract}

Keywords: supply chain risk management, failure mode and effect analysis, supplier selection, nalytic hierarchy process (AHP), VIKOR method

\section{Introduction}

In the emerging supply chain environment, supply chain risk management plays a more significant role than the past. Companies should focus not only on the efficiency of the supply chain, but also should focus on its risks. When an unpredictable event occurs, all members of the supply chain are affected (Chen \& Wu, 2013). Nowadays, many companies have turned to various activities, such as outsourcing of logistics, production, and operations, in order to gain economic benefits and market share. This made them dependent on suppliers to achieve their business goals. In today's complex and unpredictable business environment, the dependency has caused the supply chain to be more vulnerable to supply districts by a variety of disruptions (Tang, 2006). Supply chain risk management (SCRM) is required to form a system for evaluating and selecting qualified suppliers in order to reduce supply chain uncertainty (Srinivasan, Mukherjee, \& Gaur, 2011; Tang, 2006). Basically, risk identification before the occurrence, and proposing methods for preventing and dealing with them, and developing support tools for decision-making based on proper risk analysis that can be achieved through proper risk definition, is essential for business successes and selection of superior suppliers (Ravindran, 2010).

Failure Mode and Effects Analysis (FMEA) is considered as one of the most well-known engineering techniques and risk assessment tools for defining, identifying and eliminating potential problems and errors in products, processes, designs and services. In practice, this technique has been used for designing a product and improving production, but Pillay and Wang (2003) have concluded that managers can use the results of the FMEA in the face of supply chain risk and make better decisions. Therefore, the FMEA can be introduced as a tool for evaluating and selecting suppliers (Chen \& Wu, 2013). In the initial FMEA method, risk priorities for different failure modes are determined using the index of "Risk Priority Number (RPN)" that is achieved from the product of the scores of the risk factors, such as 
probability of occurrence $(\mathrm{O})$, severity of effect $(\mathrm{S})$, and rate of detection $(\mathrm{D})$.

However, the RPN method has been criticized by many scholars and experts due to its shortcomings and disadvantages, so that significant efforts have been made in literature related to the FMEA technique to deal with these shortcomings. By reviewing the literature, it is observed that former researchers have considered the supplier selection problem as a multi-criteria decision-making problem (Che \& Wang, 2008; Ho, Xu, \& Dey, 2010).

According to the capabilities of multi-criteria decision-making methods in directing the decision maker to the best alternative and the efficiency of the FMEA technique in organizing and analyzing supply chain risks, in this study, a combination of these two methods is introduced for identifying and assessing the supply chain risks and comparing and prioritizing candidate flour suppliers in the Nan Sahar Industrial group. Accordingly, the other sections of this study are organized as follows.

In the second section, the literature and background will be reviewed. The third section explains the methodology of the research and the proposed methodological framework in detail. In the following, the proposed framework is used in order to determine the weights of supply chain risks and prioritizing flour suppliers in the Nan Sahar Industrial group. In the end, the results will be discussed.

\section{Literature Review and Research Background}

Basically, significant costs and problems are created due to supply chain disruptions. In today's economy, the risk of supply chain disruptions has significantly increased due to a supplier error. After a supplier error, the reaction is often very costly and reduces the effectiveness (Giunipero, 2010). In order to improve performance and management of the supply chains in a more efficient way, the risks of the suppliers' field areas should be identified and assessed, so that they can be managed. There is a degree of suppliers risk in every business. If no measures have been taken to manage risk already, negative events will have a detrimental effect on the buyer company. Companies are facing with a variety of sources of risk to provide their inputs. The focus of the supplier's risk is on events that have detrimental outputs for sourcing programs (Giunipero, 2010). The complete elimination of suppliers risk is an unrealistic goal, but the probability of negative events can be reduced and it can be prevented from occurring. Although many researchers have studied the issue of supplier selection and assessment, but few have examined this issue based on supply chain risk (Ho et al., 2010). Levary (2007), during a study entitled "Foreign Suppliers Ranking Based on Supply Risk", using the AHP technique, provided a method to select suppliers by considering the criteria that depend on the supplier selection process. Micheli, Cagno, and Zorzini (2008) carried out a study titled "Supply risk management vs. supplier selection to manage the supply risk in the EPC supply chain". They concluded that considering competition between similar goods is often equivalent to the competition between their supply chains and conversion risk is an important category in supply chains, their study was carried out aimed to study whether Is there any relationship between supplier selection (SS) and supply risk management (SRM) in the Engineering, Procurement \& Construction (EPC) and what factors drive EPC companies to focus on SRM and SS.

Schonherr et al. (2008) in their paper titled "Assessing supply chain risks with the analytic hierarchy process: A decision support for outsourcing by an American company", provided a model that was used to assess the supply chain risks associated with the decision to outsource in the American company. In this study, the company studied was looking for a supplier for its two new production lines. There were five alternatives available to the company to find the best one and a combination of action research and analytic hierarchy process methods was used.

Ravindran et al. (2010) modeled and solved the supplier selection problem considering Supplier Risks (SR) as a multi-criteria optimization problem. They initially chose a number of suppliers using multi-objective ranking methods, and in the next step provided a model for the assignment of new orders to suppliers considering risk. Thun and Hoenig (2011) carried out a research survey on 67 German automakers in order to investigate supply chain vulnerability and assess the key drivers of their supply chain risks. They used the Probability - Impact Matrix to analyze internal and external supply chain risks. Then they offered suggestions for coping and reducing supply chain risks.

Ho et al. (2015), in an overview paper, categorized and analyzed the research literature related to supply chain risk management existing from 2003 to 2013. Then, they examined the development of research in the definition of supply chain risk, a variety of risks, risk factors, risk management, and risk reduction strategies. Finally, they analyzed the potential gaps in the literature of the supply chain risk management. Li, S., \& Zeng, W. (2016) proposes FMEA method evaluate the risks in the decision process of the supplier selection. This method makes two technical outputs for supporting risk analysis. Firstly, the FMEA document is developed to identify the supplier risks. Secondly, Risk Priority Numbers are applied to assess a discount on a supplier's performance based on their risk level. Finally, they presented a real-case example for selecting methanol suppliers in the global market based 
on risk analysis to show their proposed method capabilities. Vahidi et al. (2018) suggested a novel programming model to select sustainable supplier and solve order allocation problem under operational and disruption risks. They introduced a composed SWOT-QFD framework to identify the most effective sustainability criteria based on the manufacturer's strategies. Moreover, they applied various proactive strategies to improve the resilience level of the selected supply base. They also described a hybrid sustainability-resilience objective function to choose a resiliently sustainable supply base. In order to validate the formulated model and its solution method, some numerical examples are examined. They also used a case study to show the capability of the framework in practice. Finally, in order to illustrate the competency of their proposed aggregate sustainability-resilience objective function, they performed a sensitivity analysis. Among the risk assessment methods, FMEA is a general method for preventive risk assessment (Ko, 2013; Liu, H. C., Liu, L., \& Liu, N. 2013). Unlike other risk assessment tools and failure modes, the main approach and philosophy of the FMEA, is the emphasis on dealing with problems.

Nowadays, FMEA is widely used in various industries, including aircraft, automotive, nuclear, electronic, chemical, mechanical and medical technology industries (Chang \& Cheng, 2011; Chin et al., 2009; Sharma, Kumar, \& Kumar, 2005). Chen and $\mathrm{Wu}$ (2013) proposed a modified model for Machinery Failure Modes and Effects Analysis (MFMEA) in supplier selection problem based on supply chain risk. In order to validate the proposed model, they used this model to evaluate and rank the suppliers of one of the IC assemblers. According to their study, the proposed method enabled the company to categorize suppliers in more efficient manner and select their supply chain partner at the lowest risk simultaneously.

Basically, the Failure Modes in the FMEA is evaluated by developing the Risk Priority Number (RPN), but the RPN method has significant disadvantages and weaknesses. In the classic form of the FMEA approach, a number between 1 to 10 is considered for each of the three factors, so that 1 represents the best, and 10 indicates the worst mode. The risk priority number (RPN) is obtained from the product of the factors of the Severity of failure impact (S), the occurrence probability of failure (O) and the failure detectability (D) (Chin, Chan, \& Yang, 2008), which is equal to: $\mathrm{RPN}=\mathrm{S} * \mathrm{O} * \mathrm{D}$.

Considering the capabilities of the FMEA method with the multi-criteria decision-making methods, as well as the lack of a similar study in using these methods in supply chain risk assessment and supplier priorities, this issue is on the agenda in this study.

\section{Tools and Techniques}

Given that the proposed methodological framework of this study is based on the integration of the FMEA tool with multi-criteria decision-making techniques, including hierarchical analysis process and VIKOR method, in this section we briefly discuss each of these methods.

\subsection{Failure Modes and Effects Analysis (FMEA)}

In 1960, Failure modes and effects analysis (FMEA) was first developed as a post-design methodology by the airline industry (Bowles, \& Peláez, 1995). This technique is considered as a useful and powerful tool for evaluating potential failures and preventing them from occurring (Ravi Sankar, \& Prabhu, 2001). Intermediate teams are needed for implementing the FMEA in which a set of experts with different specializations from different departments such as design, production, process, and quality are gathered in order to examine and test the relationship between the failure modes, effects, causes, current controls, and proposed actions (Mentes, \& Helvacioglu, 2011).

The FMEA is considered as one of the well-known engineering techniques and risk assessment tools for defining, identifying and eliminating potential failures and errors in products, processes, designs, and services. As mentioned earlier, in the classic FMEA method, the risk priorities of the failure modes are determined using RPN. However the crisp RPN has been criticized by many scholars and experts due to its shortcoming, so that significant efforts being made in the literature related to the FMEA technique to deal with these shortcomings. This study aims to compensate the shortcomings of this technique in determining more accurately the weight of supply chain risks (potential failure modes) through the analytic hierarchy process method and the VIKOR method has been used for assessing, comparing and prioritizing suppliers based on all available risks.

\subsection{Analytic Hierarchy Process (AHP)}

Since in the real world, the importance of criteria and sub-criteria in evaluating a phenomenon is not equal with each other from the expert's view, therefore, the use of efficient weighting methods such as AHP will play a significant role in determining their importance. The Analytic Hierarchy Process consists of steps as follows. 


\subsubsection{Step 1) Formation of the hierarchical structure of the problem}

In the first step, the hierarchical structure of the problem is developed, so that, the overall purpose is placed on top of the hierarchy, and decision alternatives on the bottom. The criteria and sub-criteria related to decision problems are between these high and low levels. The number of levels in this hierarchical structure depends on the complexity of the problem (Majumdar, 2010). Therefore, the hierarchical analysis process requires breaking a problem with several indicators into a hierarchy of levels. The high level represents the main goal of the decisionmaking process. The second level represents the major criteria (which may be broken down into sub-criteria and more detailed criteria at the next level), and provides the final level of decision alternatives. In this study, the AHP method is used to determine the weights of criteria and sub-criteria (supply chain risks), thus the hierarchy structure of the problem will be broken down to the level of sub-criteria.

\subsubsection{Step 2) Formation of a Pairwise Comparison Matrix (PCM)}

At this stage, the relevant data is obtained in order to compare the alternatives. This requires that the decision maker makes paired comparison matrixes of elements in each level in the hierarchy relative to an activity at a higher level (Majumdar, 2010). In the absence of a real measurement criterion, the paired comparison method is considered as one of the methods used to compare different criteria. The main advantage of this method is that not only two criteria are compared at a given time, but also the interaction between them is studied in an explicit way. The comparison step is completed by asking a series of questions from managers and decision makers that compares the relative importance of the criteria (Kokangul, \& Susuz, 2009). In AHP, if a problem includes M alternatives and $\mathrm{N}$ criteria, the decision maker needs to make a $\mathrm{N}$ judge matrix of alternatives with a $\mathrm{M} \times \mathrm{M}$ rating and a judge matrix of criteria with a $\mathrm{N} \times \mathrm{N}$ rating. Finally, a decision matrix with a $\mathrm{M} \times \mathrm{N}$ rating is formed using the relative scores of alternatives according to each criterion. In AHP, the relative scales of real numbers, from 1 to 9 , and their inverse, are used in order to determine the priorities in a systematic way. When two criteria (or two alternatives) are compared at a higher level according to an indicator, the relative scale determined by Saaty is used, as explained in Table 1.

Table 1. Relative scales used to compare the criteria or alternatives with each other (Saaty, 1980)

\begin{tabular}{|c|c|c|}
\hline Preferred value & Importance level & Description \\
\hline 1 & Equal importance & $\begin{array}{l}\text { The alternative or the criterion } \mathrm{i} \text { and } \mathrm{j} \text { have equal importance. In } \\
\text { other words, they are not preferable to each other. }\end{array}$ \\
\hline 3 & Rarely important & The alternative or the criterion $\mathrm{i}$ is rarely important than $\mathrm{j}$. \\
\hline 5 & More important & The alternative or the criterion $\mathrm{i}$ is more important than $\mathrm{j}$. \\
\hline 7 & Very important & The alternative or the criterion $\mathrm{i}$ is very important than $\mathrm{j}$. \\
\hline 9 & Absolutely important & The alternative or the criterion $\mathrm{i}$ is absolutely important than $\mathrm{j}$. \\
\hline $2,4,6,8$ & Middle values & $\begin{array}{l}\text { The middle values represent the preferred values, for example, } 8 \\
\text { represents significance greater than } 7 \text { and lower than } 9 \text { for i. }\end{array}$ \\
\hline
\end{tabular}

\subsubsection{Step 3) Calculation of weights of criteria and sub-criteria and examination of matrix consistency}

At this step, the relative importance of different criteria is determined according to the goal of the problem and the scores of the sub-criteria is calculated according to each criterion. For the $\mathrm{N}$ criteria, the comparison matrix (CM) with the degree of $\mathrm{N} \times \mathrm{N}$, and the input $\mathrm{Cij}$ indicates the relative importance of the criterion $\mathrm{i}$ according to the criterion $\mathrm{j}$.

$$
\begin{gathered}
\forall \mathrm{i}=\mathrm{j}, \mathrm{C}_{\mathrm{ij}}=1 \& \mathrm{C}_{\mathrm{ij}}=\frac{1}{\mathrm{C}_{\mathrm{ji}}} \\
\mathrm{CM}=\left[\begin{array}{cccc}
1 & \mathrm{C}_{12} & \ldots & \mathrm{C}_{1 \mathrm{~N}} \\
\mathrm{C}_{21} & 1 & \ldots & \mathrm{C}_{2 \mathrm{~N}} \\
\vdots & \vdots & 1 & \vdots \\
\mathrm{C}_{\mathrm{N} 2} & \mathrm{C}_{\mathrm{N} 2} & \ldots & \mathrm{C}_{\mathrm{NN}}
\end{array}\right]
\end{gathered}
$$

The relative significance or weight of $\mathrm{i}$-th criterion $\left(\mathrm{w}_{\mathrm{i}}\right)$ is determined by calculating the Geometric Means (GM) of $i$-th row and then normalizing the Geometric Means of the mentioned matrix rows. 


$$
\mathrm{GM}_{\mathrm{i}}=\left\{\prod_{\mathrm{j}=1}^{\mathrm{N}} \mathrm{C}_{\mathrm{ij}}\right\}^{\frac{1}{\mathrm{~N}}} ; \mathrm{W}_{\mathrm{i}}=\frac{\mathrm{GM}_{\mathrm{i}}}{\sum_{\mathrm{i}=1}^{\mathrm{N}} \mathrm{GM}_{\mathrm{i}}} \text { (For positive criteria), } \mathrm{W}_{\mathrm{i}}=\frac{\frac{1}{\mathrm{GM}_{\mathrm{i}}}}{\sum_{\mathrm{i}=1 \frac{1}{\mathrm{GM}_{\mathrm{i}}}}^{\frac{1}{2}}} \text { (For negative }
$$

criteria)

After building the pairwise comparison matrix, matrix consistency must be controlled. This is done by calculating the Saaty Consistency rate for each matrix.

$$
\mathrm{CR}=\frac{\mathrm{CI}}{\mathrm{RI}}
$$

The Saaty Consistency rate is calculated by the following formula: $\mathrm{CR}=$ Consistency index / random index .

$$
\mathrm{CI}=\frac{\lambda_{\max }-\mathrm{n}}{\mathrm{n}-1}
$$

$\lambda \max$ is the largest specific value of the matrix. The random variable is extracted by Table 2 .

Table 2. Random Index (Mehregan, 2004)

\begin{tabular}{lllcccccccc}
\hline $\mathrm{N}$ & 1 & 2 & 3 & 4 & 5 & 6 & 7 & 8 & 9 & 10 \\
\hline $\mathrm{RI}$ & 0 & 0 & 0.58 & 0.9 & 1.12 & 1.24 & 1.32 & 1.41 & 1.45 & 1.51 \\
\hline
\end{tabular}

\subsection{VIKOR Method}

The VIKOR method is one of the Compromise Programming methods for solving Multi-Attributes DecisionMaking problems (MADM). This method determines the ranked list of compromise solutions for solving MADM problems and focuses on selecting a set of alternatives in the presence of conflicting criteria. In problems with inappropriate and incompatible criteria, in which the decision maker needs a solution close to the ideal solution, and all alternatives are evaluated in accordance with the criteria, also in cases where the decision maker is not able to identify and express the superiorities of a problem at the time of starting and designing it, this method can be considered as a good tool for decision making. In this method, the criteria for ranking the alternatives are based on the closeness of each one to the ideal solution. For the first time, this method was used through Tzeng and Opricovic in 2004 in cases such as earthquake and environmental engineering. Where there is a multi-criteria decision-making problems with $\mathrm{m}$-criteria, and $\mathrm{n}$ alternatives, the following steps are considered to select the best alternative:

\subsubsection{Step 1) Formation of the decision matrix}

Given the number of criteria, the number of alternatives, and the evaluation of all alternatives for different criteria, the decision matrix is formed as follows:

$$
\mathrm{D}=\left[\begin{array}{ccc}
\mathrm{X}_{11} & \cdots & \mathrm{X}_{1 \mathrm{n}} \\
\vdots & \cdots & \vdots \\
\mathrm{X}_{\mathrm{m} 1} & \cdots & \mathrm{X}_{\mathrm{mn}}
\end{array}\right]
$$

Where, $\mathrm{Xij}$ is the efficiency of $\mathrm{j}$-th criterion $(\mathrm{j}=1,2, \ldots, \mathrm{n})$ in relation to the $\mathrm{i}$-th criterion $(\mathrm{i}=1,2, \ldots, \mathrm{m})$.

3.3.2 Step 2) Determining the weight of the criteria

At this step, considering the importance factor of the various criteria in decision making, a matrix is defined as follows:

$$
\mathrm{W}=\left[\mathrm{w}_{1}, \mathrm{w}_{2}, \ldots, \mathrm{w}_{\mathrm{n}}\right]
$$

3.3.3 Step 3) Formation of the normalized decision matrix

The following equation is used to determine the elements of the normalized decision matrix.

$$
\mathrm{f}_{\mathrm{ij}}=\frac{\mathrm{x}_{\mathrm{ij}}}{\sqrt{\sum_{i=1}^{\mathrm{m}} \mathrm{x}_{\mathrm{ij}}^{2}}} ; \mathrm{i}=1,2, \ldots, \mathrm{m} ; \mathrm{j}=1,2, \ldots, \mathrm{n}
$$

3.3.4 Step 4) Determination of the best and worst value from the values available for each criterion in the decision matrix 
The best and worst value for the positive and negative criteria are calculated as shown in Table 3:

Table 3. Best and worst value for positive and negative criteria

\begin{tabular}{ccc}
\hline Criterion type & The best & The worst \\
\hline Positive criterion & $f_{i}^{*}=\max f_{i j}$ & $f_{i}^{-}=\min f_{i j}$ \\
Negative criterion & $f_{i}^{*}=\min f_{i j}$ & $f_{i}^{-}=\max f_{i j}$ \\
\hline
\end{tabular}

Where $\mathrm{f}_{\mathrm{i}}^{*}$ is the best value of the $\mathrm{i}$-th criterion and $\mathrm{f}_{\mathrm{i}}^{-}$is the worst value of $\mathrm{i}$-th criterion among all the alternatives.

\subsubsection{Step 5) Calculation of $S$ and $R$ values}

The values of $\mathrm{S}$ and $\mathrm{R}$ are calculated according to the following equations: Where, $\mathrm{W}_{\mathrm{i}}$ is the amount of weight for the i-th criterion.

$$
\begin{aligned}
S_{j} & =\sum_{i=1}^{n} w_{i} \frac{\left(f_{i}^{*}-f_{i j}\right)}{\left(f_{i}^{*}-f_{i}^{-}\right)} \\
R_{j} & =\max \left[w_{i} \frac{\left(f_{i}^{*}-f_{i j}\right)}{\left(f_{i}^{*}-f_{i}^{-}\right)}\right]
\end{aligned}
$$

3.3.6 Step 6) Calculation of the value of Q

The value of $\mathrm{Q}$ is calculated according to the following equation.

$$
\begin{gathered}
Q_{j}=v \frac{\left(S_{j}-S^{*}\right)}{\left(S^{-}-S^{*}\right)}+(1-v) \frac{\left(R_{j}-R^{*}\right)}{\left(R^{-}-R^{*}\right)} \\
R^{*}=\min _{j} R_{j}, R^{-}=\max _{j} R_{j} \\
S^{*}=\min _{j} S_{j}, S^{-}=\max _{j} S_{j}
\end{gathered}
$$

The parameter $\mathrm{V}$ is chosen according to the agreement of the decision maker group, so that in the case of high agreement, its value is more than 0.5 , in the case of the agreement with the majority of votes, it is equal to 0.5 , and in the case of low agreement, it will be less than 0.5 .

\subsubsection{Step 7) Sorting the alternatives based on decreasing values of R, S and Q:}

In this step, considering the values of R, S and Q, the alternatives are sorted in three groups. Finally, an alternative that is the superior in all three groups will be chosen as the best one. The ordering of the alternatives is due to the decrease of the values of R, S and Q. It should be noted that in the group Q, an alternative is chosen as the superior that can satisfy the following two conditions:

Condition 1) If $\mathrm{A}^{(1)}$ and $\mathrm{A}^{(2)}$ are the first and second superior alternatives in the group $\mathrm{Q}$ and $\mathrm{n}$ indicates the number of alternatives, the following equation to be true:

$$
\mathrm{Q}\left(\mathrm{A}^{(2)}\right)-\mathrm{Q}\left(\mathrm{A}^{(1)}\right) \geq \frac{1}{\mathrm{n}-1}
$$

Condition 2) The alternative $A^{(1)}$ must be recognized as the superior rank in at least one of the $\mathrm{R}$ and $\mathrm{S}$ groups. When the first condition is not satisfied, a set of alternatives is selected as the superior choices:

$$
\text { superior alternatives }=A^{(1)}, A^{(2)}, \ldots, A^{(M)}
$$

The maximum value of $\mathrm{M}$ is calculated according to the following equation:

$$
\mathrm{Q}\left(\mathrm{A}^{(\mathrm{M})}\right)-\mathrm{Q}\left(\mathrm{A}^{(1)}\right) \geq \frac{1}{\mathrm{n}-1}
$$


When the second condition is not satisfied, two alternatives $\mathrm{A}^{(1)}$ and $\mathrm{A}^{(2)}$ are selected as superior ones (Opricovic \& Tzeng, 2007).

\section{Research Methodology and the Proposed Framework}

This study is an applied research in term of objective and is considered as a descriptive-survey study in terms of the nature and the way of data gathering. In this study, the required information in relation with determining the final framework of the criteria and sub-criteria (risks) of suppliers was gathered using the literature of research and interviewing experts. In addition, the required data for the formation of pairwise comparison matrices, FMEA matrix, and decision matrix were collected through a questionnaire. Due to the limited number of experts familiar with the area under discussion in the relevant organization, the judgmental sampling method was used. Accordingly, the statistical sample is equal to the population and experts are comprising a senior manager and 5 middle-level managers in the Nan Sahar Industrial group. Given that the designed questionnaire is based on the matrix logic, so, in order to measure its reliability, the Saaty Consistency rate and for its validity, the formal content method was used. According to the results, the Consistency index for matrices was less than 0.1 and reliability of the questionnaire was passed. In addition, according to several professors and scholars' comments on the structure of the questions the validity of the questionnaire was confirmed. Figure 1 shows the proposed framework of this study schematically.

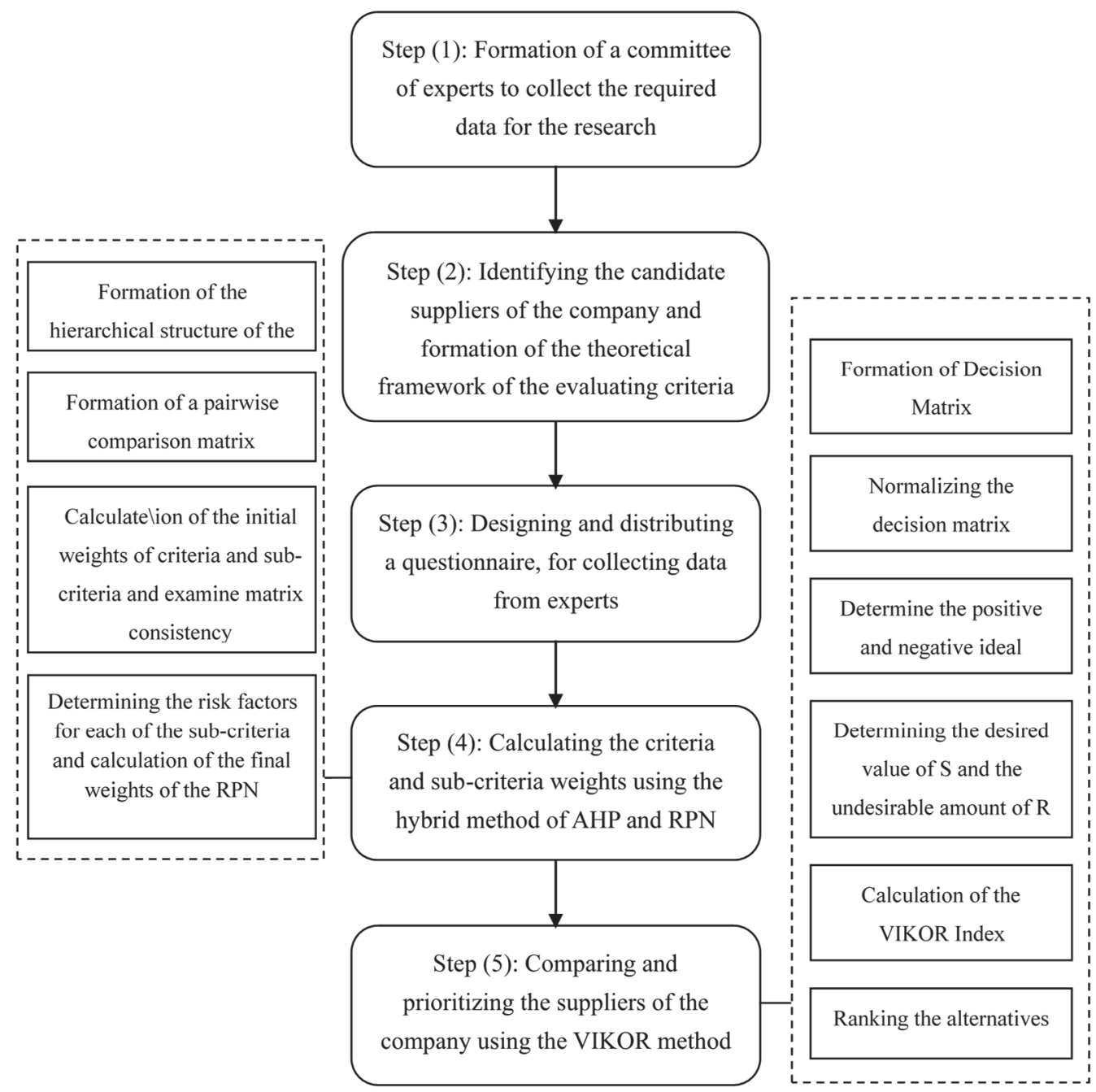

Figure 1. Proposed framework

\section{Data Analysis}

The Nan Sahar Industrial group, a reputable company in the food industry in Iran, started its activities in bread production under the name of Nan Balkhi Sahar since 1971, and since that year, while communicating with international bakeries in the European countries, has taken a long step towards improving the quality level in creation of variety and reduction in the wastes of bulk and semi-bulk breads. Nan Sahar Industrial group has been one of the most skilled and most 
technically experienced bread producers in Iran. Using experienced personnel in close proximity to the technical experts of the cereal industries, the production of bulk and semi-bulk breads with high quality and while offering new patterns of bread types, it has always taken necessary measures to provide the desired methods of bread production to the consumers and final users. So that, the establishment and development of a center for training and research on bread production make possible providing academic and user training in order to improve the skills of the bread-making workers. It should be noted that in addition to producing bulk breads, the production of various types of dietary breads is based on scientific criteria is considered as the activities of this manufacturing unit that production and supply of a variety of high-fiber breads, rice breads for diabetic and celiac patients and those who suffer from high blood pressure is one considered as the most significant one.

Flour is one of the strategic ingredients of Nan Sahar Group. During this study, the company could select its preferable supplier from 5 suppliers to supply its required flour for products. Selection of the qualified supplier to provide the company required flour could play a significant role in increasing the quality of the products, significant reduction in the cost of production and supply, increasing the satisfaction of the stakeholders and end customers, and not stopping the production line. In the following, the proposed framework (Figure 1) is described step by step for evaluating and measuring flour suppliers in the Nan Sahar Industrial Group.

\subsection{Step (1): Formation of a Committee of Experts to Collect Required Data for the Research}

In the first step, during a conversation with a number of authorities in this company, a committee of 6 experts was formed, who are aware of the issue, aimed to collect required data.

\subsection{Step (2): Identifying the Candidate Suppliers and Formation of the Theoretical Framework of the Evaluating Criteria and Sub-Criteria}

By obtaining information from the committee members, it was found that the company in order to select their suitable partner in the flour supply chain has the right to choose among the five companies that their initial qualifications are approved.

Since the committee members are facing with a variety of criteria in choosing the best supplier based on the supply chain risks, therefore it was necessary that the theoretical framework of the criteria and sub-criteria of evaluation must be extracted and finalized by applying expert comments while studying the theoretical foundations of research. In this study, the assessment criteria of the company's suppliers were provided to the Committee of Experts based on supply chain risk derived from the proposed criteria in the Chen and Wu paper (2013). By applying and agreeing experts, the final theoretical framework of criteria and sub-criteria (supply chain risks) was extracted in Table 4.

Table 4. Final theoretical framework of the criteria and sub-criteria (supply chain risks)

\begin{tabular}{ll}
\hline $\begin{array}{l}\text { Criteria } \\
\text { (Risk groups) }\end{array}$ & Sub-criteria \\
\hline \multirow{2}{*}{ Cost } & $\begin{array}{l}\text { The price of the final product } \\
\text { Fluctuation in product price }\end{array}$ \\
\hline \multirow{3}{*}{ Quality } & $\begin{array}{l}\text { Internal quality control } \\
\text { Production capabilities } \\
\text { Reliability }\end{array}$ \\
\hline \multirow{2}{*}{ Delivery } & $\begin{array}{l}\text { Timely delivery } \\
\text { Delivery duration of the order }\end{array}$ \\
\hline \multirow{3}{*}{ Production } & $\begin{array}{l}\text { Efficiency } \\
\text { Production technology } \\
\end{array}$ \\
& $\begin{array}{l}\text { Production rate } \\
\text { Responsibility to demand }\end{array}$ \\
\hline
\end{tabular}

\subsection{Step (3): Designing and Distributing a Questionnaire for Collecting Data from Experts}

In this step, after confirmation of its validity by a formal content method by the experts, a researcher-made questionnaire was developed and distributed for collecting data related to pairwise comparison matrices (in AHP method), FMEA matrix, and decision matrix (in VIKOR method) among the members of the committee.

\subsection{Step (4): Calculating the Criteria and Sub-Criteria Weights Using the Combination of AHP and RPN}

In this step, the weights (relative importance) of the criteria and sub-criteria identified in step 2 are calculated by the combined method of analytic hierarchy process and RPN numbers. Given the final theoretical framework, the final criteria and sub-criteria (Table 4), the hierarchical structure of the problem are extracted as shown in figure 2. 


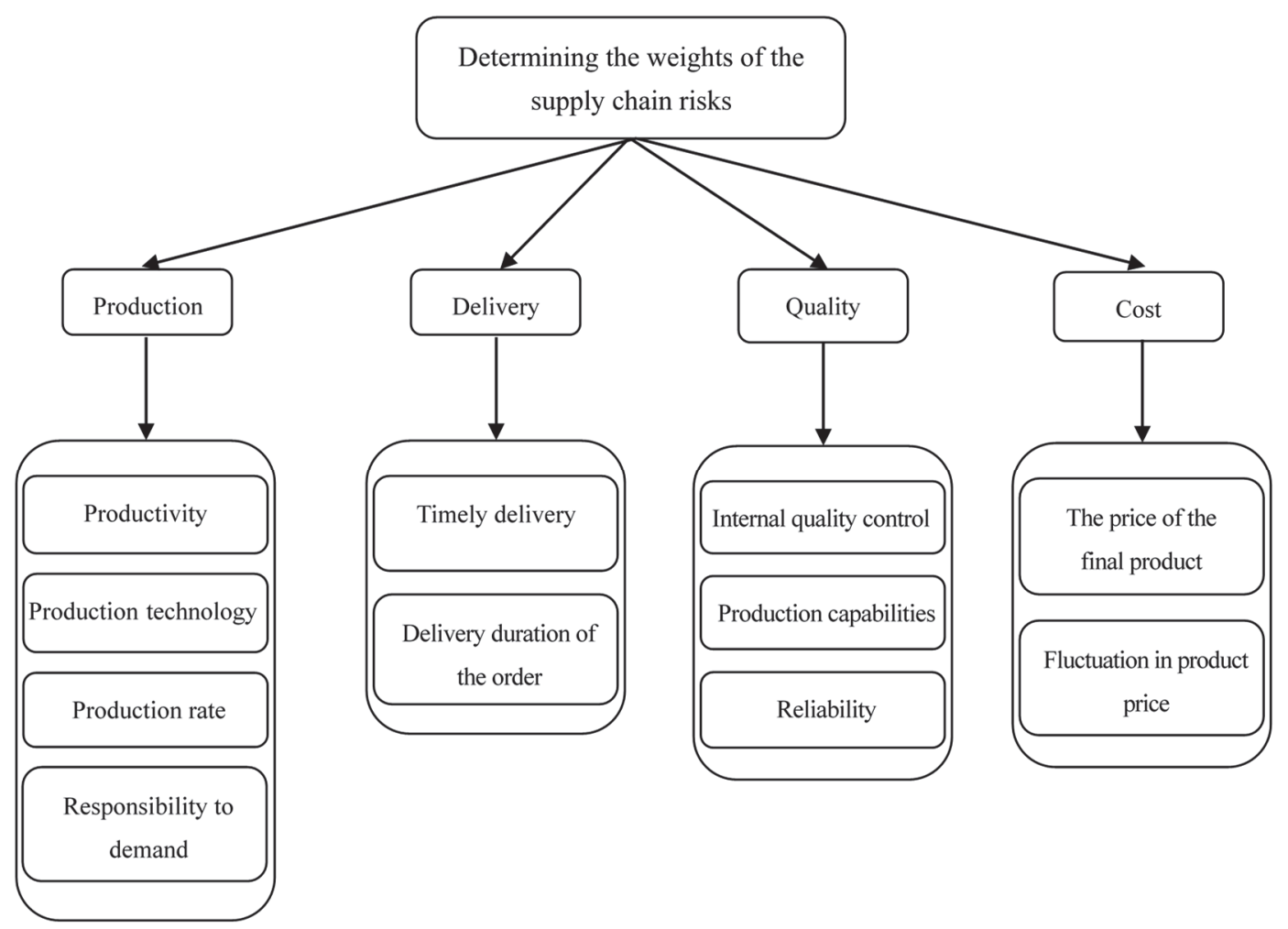

Figure 2. The hierarchical structure of the problem

After collecting the questionnaires distributed among the experts and calculating the geometric mean of the expert's views, the pairwise comparison matrices of criteria and the sub criteria along with the relative weights of each of them were calculated in tables 5-9. It should be noted that the Saaty rate value of CR in all these matrices is less than 0.1 , which indicates the reliability of the questionnaire and validates the resulting weights.

Table 5. Calculation of the weights of Criteria (Group of Risks)

\begin{tabular}{lccccc}
\hline & Cost & Quality & Delivery & Production & Final weight \\
\cline { 2 - 6 } Cost & 1 & 2.5 & 5 & 2 & 0.478 \\
Quality & 0.4 & 1 & 2 & 1.2 & 0.212 \\
Delivery & 0.2 & 0.5 & 1 & 0.5 & 0.101 \\
Production & 0.5 & 0.83 & 2 & 1 & 0.204 \\
\hline \multicolumn{2}{c}{$\lambda_{\text {Max }}=4.015$} & \multicolumn{2}{c}{$\mathrm{CI}=0.005$} & \multicolumn{2}{c}{$\mathrm{CR}=0.005$} \\
\hline
\end{tabular}

Table 6. Calculation of the weights of the sub criteria of the "cost" criterion

\begin{tabular}{ccccc}
\hline & $\begin{array}{c}\text { The price of the } \\
\text { final product }\end{array}$ & $\begin{array}{c}\text { Fluctuation in } \\
\text { product price }\end{array}$ & $\begin{array}{c}\text { Relative } \\
\text { weight }\end{array}$ & $\begin{array}{c}\text { Final } \\
\text { weight }\end{array}$ \\
The price of the final product & 1 & 1.5 & 0.6 & 0.287 \\
Fluctuation in product price & 0.67 & 1 & 0.4 & 0.191 \\
\hline$\lambda_{\operatorname{Max}}=2$ & \multicolumn{2}{c}{$\mathrm{CI}=0$} & \multicolumn{2}{c}{$\mathrm{CR}=0$} \\
\hline
\end{tabular}

Table 7. Calculation of the weights of the sub criteria of the "quality" criterion

\begin{tabular}{lccccc}
\hline & $\begin{array}{c}\text { Internal quality } \\
\text { control }\end{array}$ & $\begin{array}{c}\text { Production } \\
\text { capabilities }\end{array}$ & Reliability & $\begin{array}{c}\text { Relative } \\
\text { weight }\end{array}$ & $\begin{array}{c}\text { Final } \\
\text { weight }\end{array}$ \\
\cline { 2 - 6 } $\begin{array}{l}\text { Internal quality } \\
\text { control }\end{array}$ & 1 & 1.5 & 3 & 0.5 & 0.106 \\
\hline
\end{tabular}




\begin{tabular}{lccccc}
\hline $\begin{array}{l}\text { Production } \\
\text { capabilities }\end{array}$ & 0.67 & 1 & 2 & 0.33 & 0.071 \\
Reliability & 0.33 & 0.5 & 1 & 0.17 & 0.035 \\
\hline & $\lambda_{\operatorname{Max}}=3$ & \multicolumn{2}{c}{$\mathrm{CI}=0$} & \multicolumn{2}{c}{$\mathrm{CR}=0$} \\
\hline
\end{tabular}

Table 8. Calculation of the weights of the sub criteria of the "Delivery" criterion

\begin{tabular}{ccccc}
\hline & $\begin{array}{c}\text { Timely } \\
\text { delivery }\end{array}$ & $\begin{array}{c}\text { Delivery duration of the } \\
\text { order }\end{array}$ & $\begin{array}{c}\text { Relative } \\
\text { weight }\end{array}$ & $\begin{array}{c}\text { Final } \\
\text { weight }\end{array}$ \\
\cline { 2 - 6 } $\begin{array}{c}\text { Timely delivery } \\
\begin{array}{c}\text { Delivery duration of the } \\
\text { order }\end{array}\end{array}$ & 1 & 2.5 & 0.71 & 0.072 \\
\hline$\lambda_{\operatorname{Max}}=2$ & 0.4 & 1 & 0.29 & 0.029 \\
\hline
\end{tabular}

Table 9. Calculation of the weights of the sub criteria of the "production" criterion

\begin{tabular}{lcccccc}
\hline & Productivity & $\begin{array}{c}\text { Production } \\
\text { technology }\end{array}$ & $\begin{array}{c}\text { Production } \\
\text { rate }\end{array}$ & $\begin{array}{c}\text { Responsibility to } \\
\text { demand }\end{array}$ & $\begin{array}{c}\text { Relative } \\
\text { weight }\end{array}$ & $\begin{array}{c}\text { Final } \\
\text { weight }\end{array}$ \\
\hline $\begin{array}{l}\text { Productivity } \\
\text { Production }\end{array}$ & 1 & 1 & 2.5 & 2 & 0.3387 & 0.069 \\
technology & 1 & 1 & 2 & 3 & 0.3545 & 0.072 \\
$\begin{array}{l}\text { Production rate } \\
\begin{array}{l}\text { Responsibility to } \\
\text { demand }\end{array}\end{array}$ & 0.4 & 0.5 & 1 & 1.5 & 0.1676 & 0.034 \\
\hline \multicolumn{1}{c}{$\lambda_{\text {Max }}=4.038$} & 0.5 & 0.33 & 0.67 & 1 & 0.1308 & 0.027 \\
\hline
\end{tabular}

The final weights of the sub-criteria are calculated by obtaining the primary weights of the sub-criteria in the previous tables and applying risk factors $(\mathrm{O}, \mathrm{S}, \mathrm{D})$ and calculating risk priority numbers (RPN), and calculating their product values in the primary weights of the sub-criteria. In other words, in this process, the possibility of occurrence, the severity of the effect, and the possibility of detection of each sub-criterion (supply chain risks) are involved in determining their final RPN, so that the results are closer to reality. Table 10 shows the results of calculations of the final weights of risk priority numbers of the sub-criteria. It should be noted that the numbers of this matrix, which was introduced as the FMEA Matrix, were obtained through a questionnaire in accordance with expert opinions based on the 7-part Likert scale.

Table 10. Calculation of the final weights of RPN sub-criteria

\begin{tabular}{|c|c|c|c|c|c|c|c|c|}
\hline $\begin{array}{l}\text { Criteria } \\
\text { (Risk } \\
\text { groups) }\end{array}$ & Sub-criteria & $\mathrm{O}$ & $\mathrm{S}$ & $\mathrm{D}$ & $\mathrm{RPN}$ & $\begin{array}{l}\text { Final weights } \\
\text { of sub- } \\
\text { criteria }\end{array}$ & $\begin{array}{ll}\text { final weights of } \\
\text { sub-criteria } & \text { by } \\
\text { applying RPN } & \\
\end{array}$ & $\begin{array}{l}\text { final weights of sub- } \\
\text { criteria by applying RPN } \\
\text { (Normalized) }\end{array}$ \\
\hline Cost & The price of the final product & 3 & 2 & 1 & 6 & 0.287 & 1.72 & 0.384 \\
\hline 0.478 & Fluctuation in product price & 2 & 4 & 1 & 8 & 0.191 & 1.53 & 0.341 \\
\hline \multirow{3}{*}{$\begin{array}{l}\text { Quality } \\
0.212\end{array}$} & Internal quality control & 1 & 2 & 1 & 2 & 0.106 & 0.21 & 0.047 \\
\hline & Production capabilities & 2 & 1 & 1 & 2 & 0.071 & 0.14 & 0.031 \\
\hline & Reliability & 2 & 1 & 1 & 2 & 0.035 & 0.07 & 0.016 \\
\hline Delivery & Timely delivery & 1 & 3 & 1 & 3 & 0.072 & 0.22 & 0.048 \\
\hline \multirow[t]{2}{*}{0.101} & Delivery duration of the order & 2 & 2 & 1 & 4 & 0.029 & 0.12 & 0.026 \\
\hline & Productivity & 3 & 1 & 1 & 3 & 0.069 & 0.21 & 0.046 \\
\hline Production & Production technology & 1 & 2 & 1 & 2 & 0.072 & 0.14 & 0.032 \\
\hline \multirow[t]{2}{*}{0.204} & Production rate & 2 & 1 & 1 & 2 & 0.034 & 0.07 & 0.015 \\
\hline & Responsibility to demand & 1 & 2 & 1 & 2 & 0.027 & 0.05 & 0.012 \\
\hline
\end{tabular}

\subsection{Step (5): Comparing and Prioritizing the Suppliers of the Company Using the VIKOR Method}

In this step, VIKOR method is used to evaluate and prioritize the criteria and sub-criteria supply chain risks and select the best supplier by identifying their weights. The final decision matrix is obtained as Table 11 by collecting 
the required data from the experts, in the form of a questionnaire that indicates the status of the candidate suppliers in each sub-criterion, and calculating the geometric mean of their comments.

Table 11. Decision matrix

\begin{tabular}{lccccc}
\hline \multicolumn{1}{c}{ Alternatives } & Supplier 1 & Supplier 2 & Supplier 3 & Supplier 4 & Supplier 5 \\
\hline Sub-criteria & 54000 & 49000 & 54500 & 47500 & 51200 \\
\hline The price of the final product & 300 & 260 & 300 & 200 & 270 \\
Fluctuation in product price & 3 & 5 & 6 & 6 & 5 \\
Internal quality control & 1.6 & 2.5 & 2 & 1.5 & 2.5 \\
Production capabilities & 3.5 & 5.7 & 4.2 & 5 & 3 \\
Reliability & 0.7 & 0.83 & 0.73 & 0.95 & 0.7 \\
Timely delivery & 4 & 2 & 7 & 5 & 4 \\
Delivery duration of the order & 0.59 & 0.7 & 0.61 & 0.73 & 0.65 \\
Productivity & 6 & 5 & 5 & 4 & 3 \\
Production technology & 1800 & 2000 & 2200 & 1800 & 2000 \\
Production rate & 0.61 & 0.75 & 0.75 & 0.69 & 0.7 \\
Responsibility to demand & & &
\end{tabular}

With regard to the decision matrix extracted in Table 11 and based on the steps introduced in the VIKOR method, the normal decision matrix is obtained using the equation (8) in Table 12.

Table 12. Normal Decision Matrix

\begin{tabular}{|c|c|c|c|c|c|}
\hline Sub-criteria $\quad$ Alternatives & Supplier 1 & Supplier 2 & Supplier 3 & Supplier 4 & Supplier 5 \\
\hline The price of the final product & 0.36 & 0.08 & 0.38 & 0 & 0.2 \\
\hline Fluctuation in product price & 0.34 & 0.2 & 0.34 & 0 & 0.24 \\
\hline Internal quality control & 0.05 & 0.02 & 0 & 0 & 0.02 \\
\hline Production capabilities & 0.03 & 0 & 0.02 & 0.03 & 0 \\
\hline Reliability & 0.01 & 0 & 0.01 & 0 & 0.02 \\
\hline Timely delivery & 0.05 & 0 & 0.04 & 0.05 & 0.05 \\
\hline Delivery duration of the order & 0.01 & 0 & 0.03 & 0.02 & 0.01 \\
\hline Productivity & 0.05 & 0.01 & 0.04 & 0 & 0.03 \\
\hline Production technology & 0 & 0.01 & 0.03 & 0.02 & 0.02 \\
\hline Production rate & 0.02 & 0.01 & 0 & 0.02 & 0.01 \\
\hline Responsibility to demand & 0.01 & 0 & 0 & 0.01 & 0 \\
\hline
\end{tabular}

According to Table 12, the best and worst values for each sub-criterion is calculated as Table 13 depending on whether they belong to the profit or the cost group.

Table 13. Best and worst value for positive (profit) $\mathrm{f}_{\mathrm{i}}^{*}$ and negative (cost) $\mathrm{f}_{\mathrm{i}}^{-}$sub-criteria

\begin{tabular}{llll}
\hline Sub-criteria & $\mathrm{f}_{\mathrm{i}}{ }^{*}$ & $\mathrm{f}_{\mathrm{i}}^{-}$ & $\mathrm{f}_{\mathrm{i}}^{*}-\mathrm{f}_{\mathrm{i}}^{-}$ \\
\hline The price of the final product & 0.414 & 0.475 & -0.061 \\
Fluctuation in product price & 0.333 & 0.5 & -0.167 \\
Internal quality control & 0.524 & 0.262 & 0.262 \\
Production capabilities & 0.542 & 0.325 & 0.217 \\
Reliability & 0.581 & 0.306 & 0.275 \\
Timely delivery & 0.471 & 0.397 & 0.074 \\
Delivery duration of the order & 0.191 & 0.667 & -0.477 \\
Productivity & 0.496 & 0.401 & 0.095 \\
Production technology & 0.569 & 0.2 & 0.369 \\
Production rate & 0.501 & 0.4 & 0.091 \\
Responsibility to demand & 0.478 & 0.389 & 0.089 \\
\hline
\end{tabular}

After determining the best and worst values among the values available for positive criteria (profit) $\mathrm{f}_{\mathrm{i}}^{*}$ and the negative criteria (cost) $\mathrm{f}_{\mathrm{i}}^{-}$, in the normal decision matrix, and calculating the parameters $\mathrm{S}$ and $\mathrm{R}$ using the equations (9) and (10), the value of the VIKOR index (Q) is calculated using the equation (11) and resulted final 
ranking of the flour suppliers in the Nan Sahar Bread Industrial Group is as Table 14.

Table 14. S, R, Q values and final ranking of flour suppliers in Nan Sahar Bread Industrial Group

\begin{tabular}{lcccc}
\hline Suppliers & $\mathrm{Q}$ & $\mathrm{R}$ & $\mathrm{S}$ & Ranks \\
\hline Supplier 1 & 0.96 & 0.36 & 0.92 & Fourth \\
Supplier 2 & 0.36 & 0.2 & 0.33 & Second \\
Supplier 3 & 0.98 & 0.38 & 0.89 & Fifth \\
Supplier 4 & 0 & 0.05 & 0.13 & First \\
Supplier 5 & 0.58 & 0.24 & 0.6 & Third \\
\hline
\end{tabular}

\section{Discussion and Conclusion}

In this study, a combination of FMEA and multi-criteria decision-making techniques was proposed to evaluate the performance and prioritization of flour suppliers in the Nan Sahar industrial Group based on supply chain risks. The proposed model makes it possible for the authorities in the study to use a systematic and scientific mechanism for identifying and assessing supply chain risks and prioritizing candidate suppliers of the company rather than merely relying solely on expert judgments.

In the proposed model, the Analytic Hierarchy Process Method was used in order to determine the weights of risks identified and the VIKOR Method was used to evaluate and rank the flour suppliers. Using the AHP method with the logic of calculating RPN in the FMEA table could simultaneously take into account pair wise comparisons between criteria and sub-criteria, and risk factors including: The probability of occurrence of the risk, the severity of impact, and the detectability of the risk, the expert's opinion with more accuracy in calculating weights obtained, and the resulting weights are closer to reality. In the case study, according to the results of the calculations made, it can be concluded that the "cost" criterion with a weight of " 0.478 " was more important than the others. This suggests that this criterion plays a decisive role in selection of the best supplier from the perspective of the company's expert committee. By calculations made on determining the weights of RPN of the sub-criteria, it was observed that the sub-criteria of "final product price" sub-criteria in the cost risk group, "internal quality control" in the "quality" risk group, "timely delivery" in the risk group of "delivery", and "productivity" in the "production" risk group, have the highest weight and managers and authorities should pay more attention to these issues in the Nan Sahar Industrial Group. In the second part of the proposed model, it was determined that the weights of criteria and sub-criteria, 5 flour suppliers in the company were compared and ranked using the VIKOR method. The results of the studies indicated that the fourth supplier with the lowest value of the VIKOR index had the highest priority in the selection. In other words, this supplier has aggregately the least risk in all risk groups "cost, quality, delivery, and production" and can be considered as an appropriate choice for participation in the flour supply chain of the industrial group Sahar. The status of the priority of other suppliers was as follows.

Supplier $3<$ Supplier $1<$ Supplier $5<$ Supplier $2<$ Supplier 4

\section{References}

American Psychological Association. (1972). Ethical standards of psychologists. Washington, DC: American Psychological Association.

Anderson, C. A., Gentile, D. A., \& Buckley, K. E. (2007). Violent video game effects on children and adolescents: Theory, research and public policy. https://doi.org/10.1093/acprof:oso/9780195309836.001.0001

Beck, C. A. J., \& Sales, B. D. (2001). Family mediation: Facts, myths, and future prospects (pp. 100-102). Washington, DC: American Psychological Association. https://doi.org/10.1037/10401-000

Bernstein, T. M. (1965). The careful writer: A modern guide to English usage (2nd ed.). New York, NY: Atheneum.

Bjork, R. A. (1989). Retrieval inhibition as an adaptive mechanism in human memory. In H. L. Roediger III, \& F. I. M. Craik (Eds.), Varieties of Memory \& Consciousness (pp. 309-330). Hillsdale, NJ: Erlbaum.

Bowles, J. B., \& Peláez, C. E. (1995). Fuzzy logic prioritization of failures in a system failure mode, effects and criticality analysis. Reliability Engineering \& System Safety, 50(2), 203-213. https://doi.org/10.1016/09518320(95)00068-D

Chang, K. H., \& Cheng, C. H. (2011). Evaluating the risk of failure using the fuzzy OWA and DEMATEL method. Journal of Intelligent Manufacturing, 22(2), 113-129. https://doi.org/10.1007/s10845-009-0266-x

Che, Z. H., \& Wang, H. S. (2008). Supplier selection and supply quantity allocation of common and non-common 
parts with multiple criteria under multiple products. Computers \& Industrial Engineering, 55(1), 110-133. https://doi.org/10.1016/j.cie.2007.12.005

Chen, P. S., \& Wu, M. T. (2013). A modified failure mode and effects analysis method for supplier selection problems in the supply chain risk environment: A case study. Computers \& Industrial Engineering, 66(4), 634-642. https://doi.org/10.1016/j.cie.2013.09.018

Chin, K. S., Chan, A., \& Yang, J. B. (2008). Development of a fuzzy FMEA based product design system. The International Journal of Advanced Manufacturing Technology, 36(7-8), 633-649. https://doi.org/10.1007/s00170-006-0898-3

Chin, K. S., Wang, Y. M., Poon, G. K. K., \& Yang, J. B. (2009). Failure mode and effects analysis using a groupbased evidential reasoning approach. Computers \& Operations Research, 36(6), 1768-1779. https://doi.org/10.1016/j.cor.2008.05.002

Cress, C. M. (2009). Curricular strategies for student success and engaged learning [PowerPoint slides]. Retrieved from http://www.vtcampuscompact.org/2009/TCL_post/presenter_powerpoints /Christine\%20Cress\%20-\%20Curricular\%20Strategies.ppt

Driedger, S. D. (1998, April 20). After divorce. Maclean's, 111(16), 38-43.

Gibbs, J. T., \& Huang, L. N. (Eds.). (1991). Children of color: Psychological interventions with minority youth. San Francisco, CA: Jossey-Bass.

Gilbert, D. G., McClernon, J. F., Rabinovich, N. E., Sugai, C., Plath, L. C., Asgaard, G., ... Botros, N. (2004). Effects of quitting smoking on EEG activation and attention last for more than 31 days and are more severe with stress, dependence, DRD2 A 1 allele, and depressive traits. Nicotine and Tobacco Research, 6, 249-267. https://doi.org/10.1080/1462220041 0001676305

Giunipero, L. C. (2010). Proactively Managing Supplier Risk. ISM's 95nd Annual International Supply Management Conference, 12(2), 366-375.

Goleman, D. (2009). What makes a leader? In D. Demers (Ed.), AHSC 230: Interpersonal communication and relationships (pp. 47-56). Montreal, Canada: Concordia University Bookstore. (Reprinted from Harvard Business Review, 76(6), 93-102.

Guignon, C. B. (1998). Existentialism. In E. Craig (Ed.), Routledge encyclopedia of philosophy (Vol. 3, pp. 493502). London, England: Routledge.

Healey, D. (2005). Attention deficit/hyperactivity disorder and creativity: An investigation into their relationship (Unpublished doctoral dissertation). University of Canterbury, Christchurch, New Zealand.

Herculano-Houzel, S., Collins, C. E., Wong, P., Kaas, J. H., \& Lent, R. (2008). The basic nonuniformity of the cerebral cortex. Proceedings of the National Academy of Sciences, 105, 12593-12598. https://doi.org/10.1073/pnas.0805417105

Ho, W., Xu, X., \& Dey, P. K. (2010). Multi-criteria decision making approaches for supplier evaluation and selection: A literature review. European Journal of Operational Research, 202(1), 16-24. https://doi.org/10.1016/j.ejor.2009.05.009

Ho, W., Zheng, T., Yildiz, H., \& Talluri, S. (2015). Supply chain risk management: a literature review. International Journal of Production Research, 53(16), 5031-5069. https://doi.org/10.1080/00207543.2015.1030467

Klimoski, R., \& Palmer, S. (1993). The ADA and the hiring process in organizations. Consulting Psychology Journal: Practice and Research, 45(2), 10-36. https://doi.org/10.1037/1061-4087.45.2.10

Ko, W. C. (2013). Exploiting 2-tuple linguistic representational model for constructing HOQ-based failure modes and effects analysis. Computers \& Industrial Engineering, 64(3), 858-865. https://doi.org/10.1016/j.cie.2012.11.016

Kokangul, A., \& Susuz, Z. (2009). Integrated analytical hierarch process and mathematical programming to supplier selection problem with quantity discount. Applied mathematical modelling, 33(3), 1417-1429. https://doi.org/10.1016/j.apm.2008.01.021

Kubrick, S. (Director). (1980). The Shining [Motion picture]. United States: Warner Brothers.

Levary, R. R. (2007). Ranking foreign suppliers based on supply risk. Supply Chain Management: An International Journal, 12(6), 392-394. https://doi.org/10.1108/13598540710826317

Li, S., \& Zeng, W. (2016). Risk analysis for the supplier selection problem using failure modes and effects analysis 
(FMEA). Journal of Intelligent Manufacturing, 27(6), 1309-1321. https://doi.org/10.1007/s10845-014-09530

Liu, H. C., Liu, L., \& Liu, N. (2013). Risk evaluation approaches in failure mode and effects analysis: A literature review. Expert systems with applications, 40(2), 828-838. https://doi.org/10.1016/j.eswa.2012.08.010

Liu, S. (2005). Defending against business crises with the help of intelligent agent based early warning solutions. Paper presented at the Seventh International Conference on Enterprise Information Systems, Miami, FL. Abstract retrieved from http://www.iceis.org/iceis2005/abstracts_2005.htm

MacIntyre, L. (Reporter). (2002, January 23). Scandal of the Century [Television series episode]. In H. Cashore (Producer), The fifth estate. Toronto, Canada: Canadian Broadcasting Corporation.

Majumdar, A. (2010). Selection of raw materials in textile spinning industry using fuzzy multi-criteria decision making approach. Fibers and Polymers, 11(1), 121-127. https://doi.org/10.1007/s12221-010-0121-x

McLuhan, M. (1970a). Culture is our business. New York, NY: McGraw-Hill.

McLuhan, M. (1970b). From cliche to archetype. New York, NY: Viking Press.

Mellers, B. A. (2000). Choice and the relative pleasure of consequences. Psychological Bulletin, 126, 910-924. https://doi.org/10.1037/0033-2909.126.6.910

Mentes, A., \& Helvacioglu, I. H. (2011, January). Review of Fuzzy Set Theory Applications in Safety Assessment for Marine and Offshore Industries. In ASME 2011 30th International Conference on Ocean, Offshore and Arctic Engineering (pp. 875-884). American Society of Mechanical Engineers. https://doi.org/10.1115/OMAE2011-50244

Micheli, G. J., Cagno, E., \& Zorzini, M. (2008). Supply risk management vs supplier selection to manage the supply risk in the EPC supply chain. Management Research News, 31(11), 846-866. https://doi.org/10.1108/01409170810913042

Opricovic, S., \& Tzeng, G. H. (2007). Extended VIKOR method in comparison with outranking methods. European journal of operational research, 178(2), 514-529. https://doi.org/10.1016/j.ejor.2006.01.020

Pillay, A., \& Wang, J. (2003). Modified failure mode and effects analysis using approximate reasoning. Reliability Engineering \& System Safety, 79(1), 69-85. https://doi.org/10.1016/S0951-8320(02)00179-5

Postman, N. (1979). Teaching as a conserving activity. New York, NY: Delacorte Press.

Postman, N. (1985). Amusing ourselves to death: Public discourse in the age of show business. New York, NY: Viking.

Ravi Sankar, N., \& Prabhu, B. S. (2001). Modified approach for prioritization of failures in a system failure mode and effects analysis. International Journal of Quality \& Reliability Management, 18(3), 324-336. https://doi.org/10.1108/02656710110383737

Ravindran, A. R., Ufuk Bilsel, R., Wadhwa, V., \& Yang, T. (2010). Risk adjusted multicriteria supplier selection models with applications. International Journal of Production Research, 48(2), 405-424. https://doi.org/10.1080/00207540903174940

Saaty, T. L. (1980). The Analytic Hierarchy Process, New York, McGraw Hill. https://doi.org/10.1002/9781118445112.stat05310

Schoenherr, T., Tummala, V. R., \& Harrison, T. P. (2008). Assessing supply chain risks with the analytic hierarchy process: Providing decision support for the offshoring decision by a US manufacturing company. Journal of Purchasing and Supply Management, 14(2), 100-111. https://doi.org/10.1016/j.pursup.2008.01.008

Semenak, S. (1995, December 28). Feeling right at home: Government residence eschews traditional rules. Montreal Gazette, p. A4.

Sharma, R. K., Kumar, D., \& Kumar, P. (2005). Systematic failure mode effect analysis (FMEA) using fuzzy linguistic modelling. International Journal of Quality \& Reliability Management, 22(9), 986-1004. https://doi.org/10.1108/02656710510625248

Srinivasan, M., Mukherjee, D., \& Gaur, A. S. (2011). Buyer-supplier partnership quality and supply chain performance: Moderating role of risks, and environmental uncertainty. European Management Journal, 29(4), 260-271. https://doi.org/10.1016/j.emj.2011.02.004

Strong, E. K. Jr., \& Uhrbrock, R. S. (1923). Bibliography on job analysis. In L. Outhwaite (Series Ed.), Personnel Research Series: Vol. 1. Job analysis and the curriculum (pp. 140-146). http://dx.doi.org/10.1037/10762-000 
Tang, C. S. (2006). Perspectives in supply chain risk management. International Journal of Production Economics, 103(2), 451-488. https://doi.org/10.1016/j.ijpe.2005.12.006

Thun, J. H., \& Hoenig, D. (2011). An empirical analysis of supply chain risk management in the German automotive industry. International Journal of Production Economics, 131(1), 242-249. https://doi.org/10.1016/j.ijpe.2009.10.010

Vahidi, F., Torabi, S. A., \& Ramezankhani, M. J. (2018). Sustainable supplier selection and order allocation under operational and disruption risks. Journal of Cleaner Production, 174, 1351-1365. https://doi.org/10.1016/j.jclepro.2017.11.012

\section{Copyrights}

Copyright for this article is retained by the author(s), with first publication rights granted to the journal.

This is an open-access article distributed under the terms and conditions of the Creative Commons Attribution license (http://creativecommons.org/licenses/by/4.0/). 